\title{
The parallelism argument and the problem of moral luck
}

\author{
Anna Nyman $^{1}$ (D)
}

Accepted: 6 July 2021 / Published online: 21 July 2021

(C) The Author(s) 2021

\begin{abstract}
Robert Hartman's parallelism argument aims to show that resultant moral luck exists. The gist of the argument is this: because there is circumstantial moral luck in a particular circumstantial luck scenario and that scenario is analogous in important ways to a particular resultant luck scenario, the resultant luck scenario is plausibly an instance of resultant moral luck (and hence, resultant moral luck exists). I argue that there is a principled way of denying that circumstantial moral luck is present in the circumstantial luck scenario. Doing so is not enough, however, to reject Hartman's general analogical line of reasoning since an alternative parallelism argument based on a resultant luck scenario and a circumstantial luck scenario of another kind can be made. Nevertheless, I argue that the analogy between the circumstantial luck scenario and the resultant luck scenario in both the alternative parallelism argument and its original counterpart is too weak to support the claim that resultant moral luck is present in the resultant luck scenario.
\end{abstract}

Keywords Moral luck - Resultant moral luck - Circumstantial moral luck · Moral responsibility - The parallelism argument - Blameworthiness · Robert Hartman

\section{Introduction}

Most philosophers writing on the problem of moral luck distinguish between at least four varieties of luck - four ways in which luck affects agents' actions, where actions are considered affected by luck if they depend on factors beyond agents' control. These are luck in how things turn out (resultant luck), in what opportunities and challenges one faces (circumstantial luck), in what one is like (constitutive

Anna Nyman

anna.nyman@filosofi.uu.se

1 Department of Philosophy, Uppsala University, Box 627, 75126 Uppsala, Sweden 
luck), and in how one is affected by past states of the world and the laws of nature (causal luck). ${ }^{1}$

Where an agent's moral blame- or praiseworthiness is partially determined by luck-by factors beyond her control-there is moral luck. ${ }^{2}$ Such luck divides into four categories, echoing the four ways in which luck affects agents' actions. Thus, resultant moral luck is present when an agent's blame- or praiseworthiness is partially determined by how her actions turn out, circumstantial moral luck is present when an agent's blame- or praiseworthiness is partially determined by what opportunities and challenges she faces, and so on (assuming, of course, that it is beyond the agent's control how things turn out, what opportunities and challenges she faces, and so on).

Our judgments about blame- and praiseworthiness in particular cases indicate that we are committed to the existence of moral luck. We tend to think, for example, that a reckless driver who hits a pedestrian is more blameworthy than an equally reckless driver who does not (Nagel, 1979: 29). If she is, resultant moral luck exists. After all, factors beyond the drivers' control partially determine whether they hit a pedestrian since whether they do depends on whether a pedestrian crosses their paths.

We also tend to think, for example, that a judge who takes a bribe is more blameworthy than her colleague who does not, but would have, had she gotten the offer (Thomson, 1989: 214). If she is, circumstantial moral luck exists. After all, factors beyond the judges' control partially determine whether they take a bribe since whether they do depends on whether someone offers them one.

The existence of various kinds of moral luck, however, is incompatible with a widely accepted control principle, namely, that agents are blame- and praiseworthy for something only to the extent that it depends on factors within their control. In his seminal paper on the problem of moral luck, Thomas Nagel puts the principle this way: "one cannot be more culpable or estimable for anything than one is for that fraction of it which is under one's control" (Nagel, 1979: 28). Our adherence to the control principle and our judgments in particular cases thus give rise to a contradiction. On the one hand, we seem committed to the idea that moral luck of various kinds exists (which our particular judgments indicate). On the other, we seem committed to the idea that moral luck does not exist (which our adherence to the control principle indicates). This contradiction is what I take the problem of moral luck to consist in.

Some philosophers attempt to solve the contradiction by firmly sticking to the control principle and categorically denying the existence of moral luck (e.g., Levy, 2011; Zimmerman, 1987, 2002, 2015). Others try to account for both our adherence to the control principle and the particular judgements by limiting the scope of the

\footnotetext{
1 The categorization is Thomas Nagel's (1979: e.g., 28) although some of the labels have been coined by others.

2 In his seminal paper on moral luck, Nagel phrases the definition in terms of how we treat agents rather than in terms of what agents deserve (1979: 26). Since the philosophically interesting question is the latter, the definition should be put in these terms (or similarly), as e.g. Hartman (2017: 2) and Nelkin (2019a) observe.
} 
control principle and accepting some kinds of moral luck while denying other kinds (e.g., Nelkin, 2019b; Peels, 2015; Rescher, 1990; Richards, 1986; Rivera-López, 2016; Thomson, 1989). But there is also a third solution: to entirely abandon the control principle and accept all kinds of moral luck (e.g., Greco, 1995; Hartman, 2017). The existence of resultant moral luck, however, is contested by a large majority of those writing on the subject-when reflecting on scenarios such as the one with the reckless drivers while keeping the control principle in mind, many retract the initial judgement that the agents differ in degree of blameworthiness. ${ }^{3} \mathrm{~A}$ challenge for those who endorse the last type of solution is thus to show that resultant moral luck indeed exists. Robert Hartman has recently put forward a new argument to that effect. Roughly, he argues that we have good reasons to think that resultant moral luck exists because circumstantial moral luck exists, and there are important similarities between circumstantial luck scenarios and resultant luck scenarios (Hartman, 2017: 105-107). Hartman's so-called parallelism argument has not, however, received sustained appraisal in the literature so far. The purpose of this paper is to provide such an appraisal. More specifically, I will argue that the argument does not hold up under scrutiny. I first introduce the argument and present what I take to be an elucidating reconstruction of it (Sect. 2). I then make some clarifications that will prove important (Sect. 3), look closer at the controversial premises (Sects. 4, 5, 6) and end by emphasizing what conclusion to draw from the discussion (Sect. 7).

\section{Explicating the parallelism argument}

The parallelism argument is based on pair of comparisons between three cases-call the cases A, B and C. In each case, an assassin is hired to commit murder by gunshot, and all assassins make plans and show up to kill their target. When they are about to pull the trigger, however, their cases start to differ. When Anne, the assassin in case $\mathrm{A}$, is about to pull the trigger she suffers a sneezing fit due to allergies acting up and, therefore, does not pull the trigger. Had her allergies not acted up, she would have pulled the trigger. Beth, the assassin in case B, also has allergies but they do not act up. Beth thus gets an opportunity to pull the trigger and pulls it, but her bullet does not hit the target since a passing bird intercepts it. Finally, Claire, the assassin in case $\mathrm{C}$, gets an opportunity to pull the trigger and her bullet hits home, killing the target on the spot (Hartman, 2017: 106). ${ }^{4}$

The first comparison is between cases A and B (call this comparison "AB"). In $\mathrm{AB}$, there is circumstantial luck: due to factors beyond the agents' control (their allergies acting up or not), they face different opportunities and, therefore, perform different actions. Thus, there is potentially circumstantial moral luck in AB (since

\footnotetext{
${ }^{3}$ See Hartman (2017: 129) for an inventory of the published opinions on the existence of resultant moral luck.

${ }^{4}$ Hartman calls the assassins Sneezy, Off-Target, and Bulls-Eye. For a reminder of which case and comparison each agent belongs to I have renamed the assassins Anne (case A), Beth (case B), and Claire (case C).
} 
Beth is potentially more blameworthy than Anne). The second comparison is between cases B and C (call this comparison "BC") and in it, there is resultant luck: due to factors beyond the agents' control-a passing bird intercepting the bullet or not-they bring about different states of affairs even though they perform actions that are exactly alike. Hence, there is potentially resultant moral luck in BC (since Claire is potentially more blameworthy than Beth) (Hartman, 2017: 106).

With the stage thus set, the gist of the argument can be sketched. Hartman (2017: 106-107) argues that there are three similarities between $\mathrm{AB}$ and $\mathrm{BC}$. These are that:

(i) the two agents in each comparison have identical agency in some sense and are distinguished at least partially by luck (call this similarity "Identical Agency"),

(ii) the two agents in $\mathrm{AB}$ have very similar actual mental states to the two agents in BC (call it "Similar Mental States"), and

(iii) in each comparison, the two agents bring about morally significant events voluntarily (call it "Voluntariness").

If $\mathrm{AB}$ and $\mathrm{BC}$ are analogous in these ways, and if there is circumstantial moral luck in $\mathrm{AB}$, then we can conclude by analogy, Hartman continues, that there is plausibly resultant moral luck in BC. Hence, resultant moral luck exists.

In more detail, and with the implicit steps made explicit, the parallelism argument runs as follows:

P1. Circumstantial moral luck exists.

$\mathrm{P} 2$. If circumstantial moral luck exists, then there is circumstantial moral luck in AB.

$\mathrm{C} 1$. There is circumstantial moral luck in $\mathrm{AB}$.

P3. AB and BC have at least the following three similarities: (i) Identical Agency,

(ii) Similar Mental States, and (iii) Voluntariness.

$\mathrm{P} 4$. If $\mathrm{C} 1$ and $\mathrm{P} 3$, then there is resultant moral luck in $\mathrm{BC}$.

$\mathrm{C} 2$. There is resultant moral luck in BC.

$\mathrm{P} 5$. If $\mathrm{C} 2$, then resultant moral luck exists.

C3. Resultant moral luck exists.

A few words about the reconstruction are in order. First, Hartman presents the parallelism argument as an inductive argument from analogy, and although my reconstruction is deductively valid it does not contain any claims that Hartman is not already committed to; P4 is not intended to express the idea that the truth of the antecedent (logically or otherwise) guarantees the truth of the consequent. Rather, P4 expresses a material implication-one that Hartman must accept in light of the analogy he presses. ${ }^{5}$ Second, in my reconstruction, the parallelism argument's conclusion is the categorical claim that resultant moral luck exists. But there is also

\footnotetext{
5 An anonymous referee points out that there is an alternative reading of Hartman's argument that does not commit him to $\mathrm{P} 4$, but rather to $\mathrm{P} 4 *$ : If $\mathrm{C} 1$ and $\mathrm{P} 3$, then there is good evidence that there is resultant moral luck in BC. Nothing hinges on whether P4 is put one way or the other since the argument against the acceptance of P4 that I will present has force against both claims.
} 
another reading of the argument-one where the conclusion is the conditional claim that resultant moral luck exists if circumstantial moral luck exists. With due modifications, the criticism that I put forward in this paper holds for the conditional version of the argument as well.

Moving on: P5 is uncontentious, and I will grant P1. I do so not merely for the sake of argument, but also because it allows for the possibility to reject the parallelism argument without implying that one kind of proposed solution to the problem of moral luck - one that denies only resultant moral luck-is false. My focus will thus be on P2, P3 and P4. While I believe we ought to accept P3, I will argue that there is a principled way to reject $\mathrm{P} 2$ and that there are substantial reasons not to accept P4.

\section{Clarifying premise three}

I believe we ought to accept P3 but as Hartman's treatment of the similarities in it is brief, we must spend some time clarifying them to properly engage with the rest of the argument. Here, I thus offer some clarificatory remarks on each similarity to set the stage for the discussion of P2 and P4.

Let us start with the first similarity, Identical Agency: the two agents in each comparison have identical agency in some sense and are at least partially distinguished by luck (Hartman, 2017: 106). Usually, and roughly, "agency" refers to the exercise of an agent's capacity to perform actions (Schlosser, 2019). According to Hartman (2017: 106), the agents in AB have "subjunctively identical agency" since Anne would have taken the shot just like Beth did, had Anne been in Beth's circumstances, and the agents in BC have "actually identical agency" since they both actually take the shot in exactly similar circumstances. ${ }^{6}$ If Hartman uses "agency" orthodoxly he is thus saying that, because Anne would have exercised her capacity to take the shot in circumstances exactly similar to Beth's, Anne and Beth have identical subjunctive agency. And, because Beth and Claire do exercise their capacity to perform exactly similar actions in exactly similar circumstances, Beth and Claire have identical actual agency (Beth and Claire also have identical subjunctive agency since that is entailed by identical actual agency). This is what I take Hartman to mean when he says that the two agents in each comparison have identical agency in some sense. It is noteworthy, however, that given this the description of an action cannot include results. If it does, Beth and Claire do not have identical actual agency since Claire, but not Beth, causes the death of the target. This will prove important later on.

The second similarity, Similar Mental States, says that the two agents in AB have very similar actual mental states to the two agents in BC (Hartman, 2017: 106). What are the relevant actual mental states here? Anne and Beth both desire and intend to kill the target. They also have the following beliefs: that they have the skills to kill the target, that they will get an opportunity to pull the trigger, and that

\footnotetext{
6 Italics in original.
} 
they will cause the death of the target. Since Claire also have these actual mental states, both agents in $\mathrm{BC}$ have them too. It seems the only potentially relevant way that the actual mental states of the two agents in $\mathrm{BC}$ differ from the actual mental states of the two agents in $\mathrm{AB}$ is with regard to their willings: in $\mathrm{BC}$ both agents will themselves to pull the trigger, which both agents in $\mathrm{AB}$ do not do.

The final similarity, Voluntariness, is that "the agents in both case pairs [...] bring about morally significant events voluntarily" (Hartman, 2017: 107). It is clear what morally significant events Beth and Claire voluntarily bring about: a serious threat to the target's life and the death of the target, respectively. Less clear is what event Anne brings about voluntarily. What Hartman has in mind is perhaps that, just like Beth, she voluntarily brings about, at least for a time, a lethal threat to the target, or perhaps that she earlier brought about morally significant events by acting in certain ways with the intention of performing the assassination. The fact that Hartman does not specify what event Anne brings about voluntarily, along with what he says in his (brief) description of the similarity, seems to indicate, however, that he is really after something else. Here is the full description of the similarity: "the event of taking the shot and the event of killing the mark both depend on the agency of the relevant person. In [AB], the mere assassination attempt depends on [Beth's] voluntarily choice, and, in [BC], the successful assassination depends on [Claire's] voluntary choice" (Hartman, 2017: 106-107). If the important events are the ones Beth and Claire voluntarily bring about, I believe the similarity should be stated in terms of them. Here is my suggestion:

(iii) in each comparison, the agent who brings about the morally worse event does so voluntarily (call it "Voluntariness").

Moving forward, I assume that this is what Hartman has in mind.

With these points in place, let us turn to what I take to be the problematic premises.

\section{Rejecting premise two}

The parallelism argument's second premise says that if circumstantial moral luck exists, then there is circumstantial moral luck in AB (Hartman, 2017: 107). It does not follow, however, from the existence of circumstantial moral luck that it is present in all circumstantial luck scenarios. Therefore, circumstantial moral luck might not be present in AB even if it exists. Dana K. Nelkin raises this objection but does not much explore it (2019a). I believe, however, that it is a serious worry that warrants further consideration.

Now, if one holds that there is no circumstantial moral luck in circumstantial luck scenarios like the one Anne and Beth find themselves in, yet grants that circumstantial moral luck exists (which I have done), there must be circumstantial luck scenarios of some other kind in which circumstantial moral luck is present. A challenge thus arises, namely, to show in a principled way why there is no 
circumstantial moral luck in scenarios like the one Anne and Beth find themselves in even if there is circumstantial moral luck in other circumstantial luck scenarios.

I believe the challenge can be met by distinguishing circumstantial luck scenarios where the agents' mental states are similar from those where they are not. Consider scenarios like the one Anne and Beth find themselves in. In these, the relevant mental states of the agents are very similar: Anne and Beth have the same desire and intention, and they share many relevant beliefs. But there are circumstantial luck scenarios in which the agents' mental states differ significantly. This is so, for example, in the following case (call it "Expatriation"): Expatriate and Collaborator are inhabitants of Germany before the Nazi ascent. Expatriate's employer transfers her to Argentina in 1930, while Collaborator's employer keeps her in the country. Collaborator goes on to adopt the Nazi ideology and perform wrongful actions in accordance with it. Expatriate, however, goes on to lead a morally exemplary life in Argentina. Had Expatriate not been transferred, she would have adopted the Nazi ideology and performed wrongful actions in accordance with it, just like Collaborator. $^{7}$

Expatriate never desires or intends to perform wrongful actions that conform to the Nazi ideology, and she never believes that she will. Collaborator, by contrast, does all these things. This type of circumstantial luck scenario is thus structurally different from the type that Anne and Beth are in: both agents in $\mathrm{AB}$ desire and intend to perform wrongful actions and at some point believe that they can and will, while only one agent in Expatriation does. This structural difference allows us to deny, in a principled way, that there is circumstantial moral luck in $A B$ even if circumstantial moral luck exists. It allows us to argue, on the one hand, that it is implausible that moral luck is present in scenarios of the AB kind because it is counterintuitive that agents like Anne and Beth differ in degree of blameworthiness since their mental states are relevantly similar. And it allows us to argue, on the other hand, that it is not implausible that there is moral luck in circumstantial luck scenarios of the Expatriation kind because it is not counterintuitive that agents like Expatriate and Collaborator differ in degree of blameworthiness since their mental states are relevantly different. ${ }^{8}$

However, Hartman (2017: 15-16, 109-110) argues that an adequate reply to the parallelism argument cannot appeal to standard anti-moral luck intuitions because

\footnotetext{
7 The outline of this case is from Nagel (1979: 26). Details have been fleshed out by, e.g., Nelkin (2019a) and Hartman (2017).

${ }^{8}$ Note that there is nothing dialectically strange about making this kind of distinction; anyone who accepts the existence of circumstantial moral luck must make it since it is implausible that circumstantial luck always affects blameworthiness. Hartman (2017: 93) himself, for example, distinguishes between circumstantial luck scenarios where the circumstantial feature fully or partially damages the agent's capacity to exercise moral agency, and those where it does not. According to him the latter, but not the former, is of the kind where moral luck is present.
} 
the argument's premises do not rely on standard pro-moral luck intuitions. ${ }^{9}$ In that case, rejecting P2 by appealing to intuition might seem objectionable. I believe it is not, however. When Hartman (2017: 95-103) argues for the existence of circumstantial moral luck, he does so from certain considerations in epistemology (what they are is irrelevant for my purposes). Let us grant that his argument for the existence of circumstantial moral luck does not appeal to pro-moral luck intuitions. Even so, Hartman has not argued that there is circumstantial moral luck in $A B$ without appealing to such intuition since it does not follow from the existence of circumstantial moral luck that it is present in AB. As things stand, he therefore cannot dismiss an objection to P2 simply by pointing out that it is intuition-based.

A more serious worry is that the parallelism argument can be restated in terms of a pair of comparisons where the agents find themselves in scenarios of the Expatriation kind. Consider Dana, Emma, and Fiona, who are all inhabitants of Germany before the Nazi ascent. Dana's employer transfers her to Argentina in 1930. Emma's and Fiona's employers, on the other hand, do not transfer them anywhere. Dana goes on to live a morally exemplary life in Argentina while Emma and Fiona become Nazi collaborators. At one point, Emma happens upon an escaped, innocent prisoner and decides to kill the prisoner for fun. She takes perfect aim and pulls the trigger of her gun, but the bullet does not hit home because a bird intercepts it. Had Dana not been transferred to Argentina, she would have become a collaborator and taken a shot for fun at an escaped prisoner just like Emma does. Fiona, finally, happens upon an innocent escaped prisoner as well. She also decides to kill the prisoner for fun, takes perfect aim and pulls the trigger, killing the prisoner on the spot.

The two comparisons here are between the cases of Dana and Emma (DE) and between the cases of Emma and Fiona (EF). A parallelism argument based on this pair of comparisons (call it "the alternative parallelism argument") would look like the original except that its third premise would state that DE and EF are similar in two, rather than three, respects - and P4 would be adapted accordingly. After all, the agents in DE do not have very similar actual mental states to the agents in EF: Dana never desires to, intends to, or believe that she will, kill the prisoner for fun. DE and $\mathrm{EF}$ are similar, however, in the other two respects that $\mathrm{AB}$ and $\mathrm{BC}$ are similar: the two agents in each comparison have identical agency in some sense and are at least partially distinguished by luck, and in each comparison, the agent who brings about the morally worse event does so voluntarily.

Thus, Hartman's general line of reasoning cannot be dismissed even if we reject premise two. Note, however, that the analogy in the alternative parallelism argument is weaker than its original counterpart since the comparisons it is based on are similar in only two respects. That the analogy could become weaker with a

\footnotetext{
9 Hartman's point is not that we cannot in general appeal to a type of consideration when criticizing an argument just because the argument does not rely on that type of consideration. Rather, he takes it that the problem of moral luck is at its core a clash of (equally legitimate) intuitions and that we need arguments that do not bottom out in the standard case intuitions to make progress in the debate. He presents the parallelism argument as such an argument and therefore holds that a reply to it is adequate only if it lives up to the same dialectical standard.
} 
different set of cases is noted by Nelkin (2019a). Although she does not elaborate, I will argue (in Sect. 5) that this is a serious flaw because the two remaining similarities do not seem sufficient, together with the fact that there is circumstantial moral luck in DE, to make it plausible that there is resultant moral luck in EF. In other words, I will argue that P4 of the alternative parallelism argument is implausible.

I want to remain agnostic, however, on whether there is circumstantial moral luck in $\mathrm{AB}$ as intuitions on the matter are bound to differ. Moving forward, I thus consider $\mathrm{P} 4$ of both the alternative and the original parallelism argument. My overall point is that Hartman's line of reasoning fails regardless of whether there is circumstantial moral luck in $\mathrm{AB}$ because we have good reasons not to accept $\mathrm{P} 4$ of both the alternative parallelism argument and $\mathrm{P} 4$ of its original counterpart. Over the next two sections I make my case, taking as a starting point the original version.

\section{Premise four: the similarities}

The (original) parallelism argument's $\mathrm{P} 4$ says that if $\mathrm{AB}$ and $\mathrm{BC}$ are similar in at least the three observed ways and, in addition, there is circumstantial moral luck in $\mathrm{AB}$, then there is resultant moral luck in BC (Hartman, 2017: 107). We should accept this premise if the analogy is strong enough to provide evidence for the claim that there is resultant moral luck in BC. Whether it is, hinges on the extent to which the three similarities are relevant to there being resultant moral luck in BC and whether there are relevant dissimilarities between the two comparisons. This section sets out to explore the extent to which the similarities provide evidence for the presence of resultant moral luck in BC, and the next deals with what I take to be some relevant dissimilarities that undermine the analogy.

So: how do the three observed similarities and the additional fact that there is circumstantial moral luck in $\mathrm{AB}$ provide evidence that there is resultant moral luck in $\mathrm{BC}$ ? Hartman does not say anything to answer that question, and it is not obvious how it is supposed to work.

First, consider Identical Agency (that the two agents in each comparison have identical agency in some sense and are at least partially distinguished by luck) and Similar Mental States (that the two agents in AB have very similar relevant actual mental states to the two agents in BC). These similarities are perhaps supposed to support the claim that there is resultant moral luck in BC by mitigating the force of the intuition that Beth and Claire must be equally blameworthy. Here is how it would work. One might intuit that Beth and Claire cannot be blameworthy to different degrees (i.e., that resultant moral luck cannot be present in BC) because Beth and Claire have identical agency and because both have certain actual mental states. The force of that intuition is mitigated, one could argue, when it is pointed out that Anne and Beth are blameworthy to different degrees (i.e., that circumstantial moral luck is present in $\mathrm{AB}$ ) yet they too have identical agency in some sense and they too have these specific actual mental states. Thus, the force of the intuition that Beth and Claire cannot be blameworthy to different degrees (i.e., that resultant moral luck cannot be present in $\mathrm{BC}$ ) because they have identical 
agency and share the mental states that they do, is mitigated by pointing out these two similarities between $\mathrm{AB}$ and $\mathrm{BC}$.

It seems the second similarity, Similar Mental States, can fulfil this mitigating role. After all, if Anne and Beth are blameworthy to different degrees despite both of them desiring and intending to, and at some point believing that they can, and will, kill the target, then the fact that Beth and Claire both desire and intend to, and at some point believe that they can, and will, kill the target, is not a reason to consider them blameworthy to the same degree. ${ }^{10}$

It seems to me, however, that the first similarity, Identical Agency, does not support that Beth and Claire are blameworthy to different degrees by mitigating the force of an intuition in this way. If there is resultant moral luck in BC, then Beth and Claire would be blameworthy to different degrees while having identical actual agency. Anne and Beth, however, are blameworthy to different degrees while having identical subjunctive-not actual-agency. In other words, the kind of agency that Anne and Beth share is different from the kind of agency that Beth and Claire share. Thus, the force of the intuition that Beth and Claire must be blameworthy to the same degree (i.e. that there is no is resultant moral luck in BC) is not mitigated by pointing to the fact that Anne and Beth are blameworthy to different degrees (i.e. there is circumstantial moral luck in $A B$ ) while having identical agency too. Given this crucial difference between the kind of agency the agents in each comparison share, Identical Agency does not, even together with the other similarities and the fact that there is circumstantial moral luck in $A B$, seem to provide any evidence that there is resultant moral luck in BC.

What about the final similarity, Voluntariness? It says that in each comparison, the agent who brings about the morally worse event does so voluntarily. Hartman does not elaborate on how the similarity provides evidence for the presence of resultant moral luck in $\mathrm{BC}$, and it cannot support there being resultant moral luck in $\mathrm{BC}$ in the way Similar Mental States does. One straightforward possibility is that the thing that in itself makes Beth more blameworthy than Anne is that she voluntarily brings about a morally worse event than Anne does. If Beth is more blameworthy than Anne because she voluntarily brings about a morally worse event than Anne voluntary does (a more serious threat to the target's life), then the fact that Claire also voluntarily brings about a morally worse event than Beth voluntarily does (the death of the target rather than a serious threat to the target's life) supports the conclusion that Claire is more blameworthy than Beth. However, the morally worse event is the result of Beth's action. Hence, if we say that Beth is more blameworthy than Anne because she brings about a morally worse event than Anne, we are saying that Beth is more blameworthy than Anne because her action had a different (morally worse) result. That is, we are saying that an action's result can affect an agent's degree of blameworthiness (i.e., that resultant moral luck exists). But any

\footnotetext{
${ }^{10}$ Note that one cannot resist the analogy here by pointing out that while Anne and Beth have similar relevant actual mental states, Beth and Claire have identical relevant actual mental states. That is perhaps a relevant dissimilarity between the comparisons, but it does not change the fact that Similar Mental States provides at least some support for the claim that there is resultant moral luck in BC in the way suggested above.
} 
appeal to that claim is dialectically illegitimate in this context, as it is precisely the claim at issue.

One might object that we need not simply assume that results can affect blameworthiness. Rather, we could say that it is intuitively plausible that an agent who voluntarily brings about a morally worse event than another is more blameworthy, and that what makes her more blameworthy is precisely that she brings about a morally worse event voluntarily. It would thus be intuitively plausible that Beth is more blameworthy than Anne because Beth voluntarily brings about a morally worse event, and that Claire is more blameworthy than Beth because Claire voluntarily brings about a morally worse event. But in that case, the analogy does no work in establishing that there is resultant moral luck in $\mathrm{BC}$; the parallelism argument would be redundant as one could go directly from that intuition to there being resultant moral luck in BC. (Alternatively, instead of appealing to a principle-level intuition, one could appeal to a case intuition and say that it is intuitively plausible that, in $\mathrm{AB}$, Beth is more blameworthy than Anne because she brings about a morally worse event. But in that case too, the parallelism argument becomes redundant.)

Unless there is some other way in which Voluntariness supports the existence of resultant moral luck in $\mathrm{BC}$ - and I cannot see what it would be-it seems that the similarity does not provide any support for the claim that there is resultant moral luck in BC, even when taken together with Identical Agency, Similar Mental States, and the fact that there is circumstantial moral luck in AB.

Thus far, I have argued that out of the similarities Identical Agency, Similar Mental States, and Voluntariness, it is only Similar Mental States-that the two agents in $\mathrm{AB}$ have very similar relevant actual mental states to the two agents in $\mathrm{BC}$ - that in conjunction with the fact that there is circumstantial moral luck in $\mathrm{AB}$ provides any evidence that there is resultant moral luck in $\mathrm{BC}$. What does this imply for $\mathrm{P} 4$ of the original parallelism argument? The premise says that the three similarities and the fact that there is circumstantial moral luck in $\mathrm{AB}$ are sufficient to make it plausible that there is resultant moral luck in BC. That does not rule out, however, that a smaller number of similarities can play the same role. It could thus be that the remaining similarity is enough (together with the fact that there is circumstantial moral luck in $\mathrm{AB}$ ) to make it plausible that resultant moral luck is present in $\mathrm{BC}$.

Now, one relevant similarity does not make for a strong analogy. The fact that Similar Mental States mitigates the force of the intuition that there is no resultant moral luck in $\mathrm{BC}$ does not alone provide enough evidence to conclude that there is resultant moral luck in $\mathrm{BC}$. Consequently, if my case is convincing thus far, I believe we have good reasons not to accept P4. And I will argue that the reasons get stronger as we consider the relevant differences in the next section. But before moving on, let us take stock of what the discussion so far implies for the alternative parallelism argument.

The alternative parallelism argument works just like the original one but is based on a pair of comparisons, DE and EF, where the mental states of the two agents in one comparison are not very similar to the mental states of the two agents in the other comparison. Its fourth premise would say that it is plausible that there is 
resultant moral luck in EF because $\mathrm{DE}$ and $\mathrm{EF}$ are similar in at least two respects and because, in addition, there is circumstantial moral luck in DE. The two similarities, however, would be that the two agents in each comparison have identical agency in some sense and that in each comparison, the agent who brings about the morally worse event does so voluntarily-in other words, precisely the two similarities that have turned out not to provide any evidence for the claim that there is resultant moral luck in the resultant luck scenario. Thus, the alternative parallelism argument's P4 should be rejected because the two similarities it invokes-Identical Agency and Voluntariness-do not, even in conjunction with the claim that there is circumstantial moral luck in DE, make it plausible that there is resultant moral luck in EF. We need not look further, then, to conclude that the alternative parallelism argument fails.

\section{Premise four: the dissimilarities}

Since it seems that only the second similarity, Similar Mental States, provides some evidence that there is resultant moral luck in BC, the analogy appears substantially weakened. I believe, in addition, that the comparisons differ in ways that further undermine the analogy. More precisely, I will argue that the comparisons differ in three ways which provide substantial evidence against $\mathrm{P} 4$ of the original parallelism argument. These are that: (iv) the two agents in $\mathrm{AB}$, unlike the two agents in $\mathrm{BC}$, actually perform different free actions (6.1), (v), the two agents in $\mathrm{AB}$, unlike the two agents in $\mathrm{BC}$, have different willings (6.2), and (vi) the two agents in $\mathrm{BC}$, unlike the two agents in $\mathrm{AB}$, are distinguished by luck alone (6.3).

\subsection{Actual free action}

Hartman considers and rejects an objection based on dissimilarity (iv), namely, that while Anne and Beth do not actually, freely perform identical actions, Beth and Claire do. He puts the objection in terms of a supervenience principle where degree of blameworthiness supervenes on actual, free action. ${ }^{11}$ I do not think that is the best way to put it, however, because it seems a stronger claim than necessary.

Rather, I suggest the dissimilarity can be turned into an objection in the following way: if it is plausible that what makes Beth more blameworthy than Anne is that she (actually, freely) performs a different, morally worse, action than Anne, then the fact that Anne and Beth differ in degree of blameworthiness (i.e. that there is circumstantial moral luck in $\mathrm{AB}$ ) does not provide any evidence that Claire is more blameworthy than Beth (i.e. that there is resultant moral luck in BC). After all, this particular explanation for why Beth is more blameworthy than Anne cannot apply to BC since Claire does not actually, freely perform a morally worse action than Beth. If Beth and Claire differ in degree of blameworthiness then what would make them blameworthy to different degrees is not that they perform different actions, but that

\footnotetext{
11 See Hartman (2017: 109) for the original formulation.
} 
Claire causes a morally worse event than Beth. ${ }^{12}$ That speaks against $\mathrm{P} 4$ because it indicates that Anne and Beth's being blameworthy to different degrees does not lend any support to the claim that Beth and Claire differ in degree of blameworthiness, even when combined with the fact that there are certain relevant similarities between $\mathrm{AB}$ and $\mathrm{BC}$.

Of course, this does not rule out that Beth and Claire are blameworthy to different degrees since they cause different events, but my aim is not to give a direct argument against the presence of resultant moral luck in BC. My point is rather that, because the explanations of what would make the two agents in each comparison blameworthy to different degrees differ, we have reasons to doubt that the three observed similarities between $\mathrm{AB}$ and $\mathrm{BC}$, together with the fact that there is circumstantial moral luck in $\mathrm{AB}$, make it plausible that there is resultant moral luck in $\mathrm{BC}$. And while this is not evidence against the presence of resultant moral luck in $\mathrm{BC}$, it is evidence against $\mathrm{P} 4$.

\subsection{Willings}

Dissimilarity (v) - that the agents in $\mathrm{BC}$ have identical willings but the agents in $\mathrm{AB}$ do not-can be drawn from an argument by Andrew Khoury concerning what the proper objects of blame- and praiseworthiness are. He argues that agents can be blameworthy only for their inner willings (Khoury, 2018: 1358). ${ }^{13}$ On this view, two agents cannot differ in degree of blameworthiness if they do not differ in their willings and hence, it is relevant that the agents in $\mathrm{AB}$ have different willings (Beth wills herself to pull the trigger but Anne does not) while the agents in BC have identical willings (Beth and Claire both will themselves to pull the trigger). That Anne and Beth differ in this way provides evidence against P4 because it shows that the fact that Anne and Beth differ in degree of blameworthiness is not a reason to consider Beth and Claire blameworthy to different degrees even if $\mathrm{AB}$ and $\mathrm{BC}$ are similar in the three observed ways.

Two things are worth clarifying here. First, one might suspect that this is ultimately the same dissimilarity as (iv) because it might seem like an agent cannot will herself to perform an action unless she also performs that action. But she can. Consider the following case: "Lee is an assassin who reasonably believes that he has placed himself near a window on the fifth story of a building overlooking Elm Street. He reasonably believes that he carefully and skilfully draws a bead on his target. He reasonably believes that he pulls the trigger [...]" (Khoury, 2018:

\footnotetext{
${ }^{12}$ Recall that Hartman presupposes that consequences do not affect what action an agent has performed when claiming that Beth and Claire have identical actual agency (see Sect. 3), such that Claire cannot be said to perform a morally worse action than Beth in the way Beth can be said to perform a morally worse action than Anne.

13 Some might find willings metaphysically suspicious. Khoury conceives of willings as the mental events that are left after all contingent results have been stripped from an action. On this understanding, he argues, their existence should be uncontroversial (see p. 1364).
} 
1360). ${ }^{14}$ It seems plausible that Lee wills himself to pull the trigger here. The case has a twist, however. Unbeknownst to Lee, he has "recently had his brain removed from his skull, placed in a vat of liquid, and hooked up to a computer which simulates the external environment" (ibid.). So, Lee wills himself to pull the trigger but fails to do so because he no longer has a body. If one can will oneself to act, yet fail to act, willing and acting are two different matters. Hence, we have two dissimilarities here, not one.

Second, one might suspect that this dissimilarity is irrelevant unless one shares Khoury's view that we are blameworthy for our willings only. That is not the case, however, since the same reasoning used to make an objection out of (iv) can be applied here too. That is to say, if it is plausible that what makes Beth more blameworthy than Anne is that Beth wills herself to perform a different (morally worse) action than Anne does, then the fact that Anne and Beth differ in degree of blameworthiness would not provide any evidence for the claim that Claire is more blameworthy than Beth. After all, this particular explanation for why Anne and Beth differ in degree of blameworthiness cannot apply to BC, since Beth and Clare have identical willings. That speaks against P4 because it indicates that Anne and Beth's being blameworthy to different degrees is no evidence that Beth and Claire differ in degree of blameworthiness, even when combined with the fact that there are certain relevant similarities between $\mathrm{AB}$ and $\mathrm{BC}$.

Again, this would not rule out that Beth and Claire are blameworthy to different degrees because they cause different events. And again, pointing that out would not take the edge off the criticism since I am not arguing directly against the presence of resultant moral luck in $\mathrm{BC}$. I am simply trying to show that the fact that $\mathrm{AB}$ and $\mathrm{BC}$ are similar in the three observed ways and that there is circumstantial moral luck in $\mathrm{BC}$ is not enough to make it plausible that there is resultant moral luck in BC.

\subsection{Luck}

There is also, I believe, a third relevant dissimilarity between the comparisons: (vi) the two agents in $\mathrm{BC}$, unlike the two agents in $\mathrm{AB}$, are distinguished by luck alone. To see this, consider $\mathrm{BC}$ to begin with. In $\mathrm{BC}$, the agents have the same desire and intention, they both believe that they can and will kill the target, they both get an opportunity to take the shot and take it-reasonably expecting that the bullet will hit home. The only thing that distinguishes Beth's case from Claire's is that a bird intercepts Beth's bullet, but not Claire's - in other words, the only thing that distinguishes the two agents' cases is a matter of luck. Now consider AB. Granted, Anne and Beth are distinguished by luck because they are distinguished by the fact that Beth, but not Anne, gets an opportunity to pull the trigger. But there is also a further difference between them: Beth pulls the trigger, while Anne does not. That Beth gets an opportunity to pull the trigger is a matter of luck; that she pulls the trigger once she has gotten the opportunity is not. And while it seems counterintuitive that two agents who are distinguished by luck alone are

14 Khoury uses the case to make a different point. 
blameworthy to different degrees, it does not seem counterintuitive (or at least less counterintuitive) that two agents who are distinguished only partly by luck are blameworthy to different degrees. Therefore, the presence of resultant moral luck in $\mathrm{BC}$ is not made plausible by the presence of circumstantial moral luck in $\mathrm{AB}$ even if $\mathrm{AB}$ and $\mathrm{BC}$ are similar in the three observed respects. Thus, (vi) is yet another factor that speaks against $\mathrm{P} 4$.

One might want to insist that if we recall that Anne, given the opportunity, would have pulled the trigger just like Beth and if we keep that fact firmly in mind, then we can see that the difference between Anne and Beth is also due to luck alone, after all. The truth of the counterfactual claim that Anne would have pulled the trigger given the opportunity does not show, however, that it is a matter of luck whether Beth pulls the trigger-it does not show that Beth does not control whether to pull the trigger. Remember that I do not deny that the difference between Anne and Beth is due partly (or even mostly) to luck but only that it is due to luck alone.

Concerning $\mathrm{P} 4$, I have in sum argued that only one of the three similarities between $\mathrm{AB}$ and $\mathrm{BC}$ that Hartman brings attention to, together with the claim that there is circumstantial moral luck in $\mathrm{AB}$, provides evidence for the claim that resultant moral luck is present in BC. In addition, I have argued that the comparisons differ in three ways which undermine the analogy. Taken together, these considerations make up a good case against the acceptance of P4 since it seems the analogy is too weak to provide evidence that there is resultant moral luck in BC. Undoubtedly, this objection is not conclusive, and proponents of the parallelism argument may weigh the various similarities and dissimilarities differently. Nevertheless, I believe I have at least provided the agnostic inquirer with good reasons not to accept P4.

\section{Concluding remarks}

The parallelism argument says that resultant moral luck exists because circumstantial moral luck exists and there are strong parallels between a specific resultant luck scenario ("BC") and a circumstantial luck scenario ("AB") in which there is also circumstantial moral luck. The argument promises to show that resultant moral luck exists and thereby promises to provide some justification for the current practice, called into question by the denial of resultant moral luck, of blaming and punishing agents that are successful in their morally bad endeavors more harshly than those who are unsuccessful. In addition, since the argument has a conditional reading, it promises to show that the most common position on resultant moral luck in the philosophical debate (to deny its existence) is untenable unless one also denies circumstantial moral luck-a commitment far fewer seem willing to take on.

I have argued that the argument fails even if the existence of circumstantial moral luck is granted. Specifically, I have argued that there is a principled way to reject the claim that there is circumstantial moral luck in $\mathrm{AB}$, although I have remained agnostic as to whether we ought to. Rejecting this claim is not enough though, I have further argued, to show that Hartman's general line of reasoning fails since an alternative parallelism argument can be made. Nevertheless, I have, finally, argued 
that the parallels between the scenario in which there is circumstantial moral luck and the resultant luck scenario are not strong enough to make it plausible that there is resultant moral luck in the resultant luck scenario, and that this goes for both the alternative parallelism argument and its original counterpart. Differently put, I have argued that the analogy between the circumstantial luck scenario and the resultant luck scenario is too weak to give us reason to accept that there is resultant moral luck in the resultant luck scenario. The conclusion to draw from my criticism is not that resultant moral luck does not exist, but that Hartman's parallelism argument fails to show that it does. As the conditional reading of his argument is vulnerable to the same criticism (with due modifications), Hartman's parallelism argument does not live up to its promises.

Acknowledgements For their valuable comments and invaluable encouragement, I am very grateful to Erik Carlson, Jens Johansson, and Maria Svedberg. Many thanks also to the participants at the Higher Seminar of Practical Philosophy at Uppsala University, to Trulsa Kempe Edebol, and to two anonymous reviewers for their helpful comments.

Funding Open access funding provided by Uppsala University. No financial support was received from any organization for the submitted work.

\section{Declaration}

Conflicts of interest The author have no relevant financial or non-financial interests to disclose.

Open Access This article is licensed under a Creative Commons Attribution 4.0 International License, which permits use, sharing, adaptation, distribution and reproduction in any medium or format, as long as you give appropriate credit to the original author(s) and the source, provide a link to the Creative Commons licence, and indicate if changes were made. The images or other third party material in this article are included in the article's Creative Commons licence, unless indicated otherwise in a credit line to the material. If material is not included in the article's Creative Commons licence and your intended use is not permitted by statutory regulation or exceeds the permitted use, you will need to obtain permission directly from the copyright holder. To view a copy of this licence, visit http:// creativecommons.org/licenses/by/4.0/.

\section{References}

Greco, J. (1995). A second paradox concerning responsibility and luck. Metaphilosophy, 26(1/2), 81-96. Hartman, R. J. (2017). In defense of moral luck: Why luck often affect praiseworthiness and blameworthiness. Routledge.

Khoury, A. C. (2018). The objects of moral responsibility. Philosophical Studies, 175(6), 1357-1381.

Levy, N. (2011). Hard luck: How luck undermines free will and moral responsibility. Oxford University Press.

Nagel, T. (1979). Moral luck. In T. Nagel (Ed.), Mortal questions (pp. 24-38). Cambridge University Press.

Nelkin, D. K. (2019a). Moral luck. In E. N. Zalta (Ed.), The Stanford Encyclopedia of Philosophy. Retrieved September 21, 2020, from https://plato.stanford.edu/archives/sum2019/entries/ moral-luck/.

Nelkin, D. K. (2019b). Thinking outside the boxes of moral luck. Midwest Studies in Philosophy, 43(1), 7-23.

Peels, R. (2015). A modal solution to the problem of moral luck. American Philosophical Quarterly, 52(1), 73-87. 
Rescher, N. (1990). Luck. Proceedings and Addresses of the American Philosophical Association, 64(3), $4-19$.

Richards, N. (1986). Luck and desert. Mind, 95(378), 198-209.

Rivera-López, E. (2016). How to reject resultant moral luck alone. Journal of Value Inquiry, 50(2), 415-423.

Schlosser, M. (2019). Agency. In E. N. Zelta (Ed.), The Stanford Encyclopedia of Philosophy. Retrieved September 21, 2020, from https://plato.stanford.edu/archives/win2019/entries/agency/.

Thomson, J. J. (1989). Morality and bad luck. Metaphilosophy, 20(3), 203-221.

Zimmerman, M. J. (1987). Luck and moral responsibility. Ethics, 97(2), 374-386.

Zimmerman, M. J. (2002). Taking luck seriously. The Journal of Philosophy, 99(11), 553-576.

Zimmerman, M. J. (2015). Moral luck reexamined. In D. Shoemaker (Ed.), Oxford studies in agency and responsibility. (Vol. 3). Oxford University Press. https://doi.org/10.1093/acprof:oso/ 9780198744832.003 .0008

Publisher's Note Springer Nature remains neutral with regard to jurisdictional claims in published maps and institutional affiliations. 